$$
\text { TID-20432 }
$$

\title{
POTENTIAL REQUIREIENTS FOR FISSION PRODUCTS AS HEAT AND RADIATION SOURCES
}

Facsimile Price $\$ \_z, \angle d$
Microfilm Price $\$<1<$
Available from the
Office of Technical Services
Department of Commerce
Washington 25, D. C.

Division of Isotopes Development

U. S. Atomic Energy Coumission Washington, D. C. 20545

January 1964

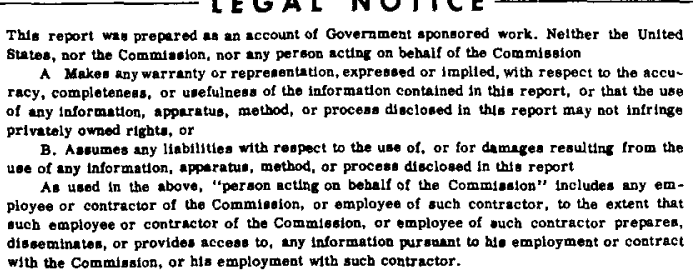

with the Commession, or hls employment with sucb contractor. 


\section{DISCLAIMER}

This report was prepared as an account of work sponsored by an agency of the United States Government. Neither the United States Government nor any agency Thereof, nor any of their employees, makes any warranty, express or implied, or assumes any legal liability or responsibility for the accuracy, completeness, or usefulness of any information, apparatus, product, or process disclosed, or represents that its use would not infringe privately owned rights. Reference herein to any specific commercial product, process, or service by trade name, trademark, manufacturer, or otherwise does not necessarily constitute or imply its endorsement, recommendation, or favoring by the United States Government or any agency thereof. The views and opinions of authors expressed herein do not necessarily state or reflect those of the United States Government or any agency thereof. 


\section{DISCLAIMER}

Portions of this document may be illegible in electronic image products. Images are produced from the best available original document. 


\section{Introduction}

This report outlines the potential applications and guantity requirements of fission products for the period 1964-1968. An evaluation is also made of the areas in which isotopes have a decided technical or logistic advantage as compared to areas where their use is more cost-dependent.

The data herein were obtained from the U. S. Coast Guard, U. S. Navy, U. S. Air Force, U. S. Weather Bureau, NASA, and commercial firms, as well as from AEC project managers for isotopic power and process radiation development. The basis for the data is contained either in formal requirements letters to the AEC from user groups, market surveys, or in other published reports, as well as from discussions.

The requirements identifled for fission products are the calculated over-all requirements which appear to be the best targets for heat source and radiation applications. The statement of requirements represents best judgments, based on existing information as to the magnitude of fission product needs through the period 1964-1968. Approximately 9100 electrical watts (27 megacuries Strontium-90) are considered to have a high probability of being used during this period. After 1968 it is expected that the use of heat and radiation sources will increase at an expanded rate, due to large-scale separation of low-cost fission products.

\section{Description of Programs}

\section{A. Military Applications}

1. Marine Navigational Aids - Underwater acoustic beacons are required to provide navigational assistance to naval vessels at thries when other navigational aids are inoperable or unavailable. Twelve to twenty such systems, requiring 10-watt power supplies, are envisaged during the period 1964 to 1966. As many as two hundred additional systems may be required in 1967 to 1970. New York Operations office of the AEC has selected two firms for the development of a series of Strontium-90 fueled generators at the 10watt level with growth potential to 20,60 and 200 watts (e) levels.

2. Oceanographic and Weather Buoys - It is extremely desirable to obtain long-term, synoptic observation of oceanographic data such as temperature, salinity, and current velocity and direction at various depths for data correlation in underwater acoustic experiments. The Navy Hydrographic Office could increase the reliability of its measurements if long-term data collecting buoys were available. A network of approximately one-hundred buoys similar to the NOMAD and MAMOS buoys is desired. Each buoy would require a power supply of at least 20 watts (e) output. 
Automatic weather stations and underwater research stations are of interest to such groups as the Navy's Hydrographic Office, Oceanographic Office, Electronics Laboratory, Underwater Sound Laboratory, Ordnance Laboratory', Radiological Defense Laboratory, as well as to the Scripps Institute of Oceanography, National Academy of Sclences and National Research Council.

3. Miscellaneous Military Programs - The Military has need for power generators in classified programs at remote locations.

4. Military Communication Satellite - AEC has executed contracts with two firms for development of a 30-watt(e) Strontium-90 fueled generator for the Medium Altitude Communications Satellite program.

B. Other Government and Civilian Applications

1. Land-Based Weather Stations (Weather Bureau, State Department, and Army) - As a result of the success of the AEC-U. S. Weather Bureau's Axe1 Heiberg Weather Station and its five-watt Strontium-90 generator, the World Meteorological Organization (WMO) has recommended the installation of additional automatic weather stations in remote areas throughout the world. They would supply synoptic weather data from areas where none is presently obtained. The State Department has shown some interest in obtaining funding for such system. The automatic weather stations for a synoptic system would require an average power of 20 watts. The Army is interested in collecting such data at potential dam sites in remote areas.

2. Coast Guard Beacons - Nuclear power supplies are economically sound for use in approximately ninety exisfing light buoys in the Alaskan area and in approximately seventy fixed lights in hazardous locations. The power required varies from 5 to 100 watts. It is expected that a considerable number of installations could be made during the next five years from an existing total of 8,624 fixed lights and 3,426 lighted buoys now powered by battery or acetylene.

3. Unattended Seismic Stations - Lamont Geological Observatory of Columbia University is interested in building a seismic station to be placed in an underseas location at a depth of approximately 20,000 feet. Power is to be provided by a radioisotope-thermoelectric generator. Such a device could provide for over-all ocean coverage in a network involving 50 to 100-watt generators. Applications of this power source for other segments of the Vela Broject (on land) would be considered where reliance on electric power lines or batteries may not be entirely desirable and maximum operational life is needed. 
4. Miss1le Range Underwater Splash Detector (now identified as SHIPTENDED ACOUSTIC RELAY - (STAR) - The complete prototype STAR system will consist of three ship-position transponders, two long-range SOFAR's, and a missile impact detection system consisting of an array of five to seven units. A one-year operational life is probably adequate for the missile impact arrays as there is apparently some operational desirability in shifting the position of the range bullseye periodically. The ship-position transponder system and the long-range $\operatorname{SOFAR}^{\circ} 8$, however, would be permanently installed, and maximum operational 1 ife is desired. Here, radioisotope power supplies would be beneficial. If the prototype STAR system works properly, there is an ultimate market requirement for many 10-watt units. An important correlary advantage in the use of radiolsotope generators would be to eliminate the costly recal1bration and position fixing that must be done every time the arrays would be disturbed to replace battery packs. Such a system could also have potential application for locating downed astronauts.

5. AMR, PMR, Weather Bureau and Navy Weather Service - During the next five years, at least thirty-five additional weather buoys similar to NOMAD and MAMOS will be deployed to supplement the meager weather data available from the ocean areas. These buoys will transmit air/water temperatures, barometric pressure, and wind speed and direction on a six-hour schedule. During storms the reporting schedule changes to hourly transmissions automatically. The Weather Bureau has under contract the development of the MAMOS Weather Buoy. The Navy Weather Service planned nine new NOMAD weather buoys in service in 1963. These buoys required pover in the 20 to 60 watts range. Although all but one of these will be powered by batteries, the buoys are adaptable to installation of radiolsotope power supplies. The successful operation of the AEC's SNAP 7D radioisotope power system and the availability of radiom isotope power supplies, econonically competitive with other power supplies, could bring about the changeover.

6. Underwater Cable Repeaters - Small power supplies are needed for undersea communication cables - both civilian and military. Small batteries are now used along the cables to boost communications signals. These batteries require replacement yearly - a very expensive operation in which the cable must be hauled out of the water to give access to the batteries. The AEC is sponsoring the development of radioisocope power supplies in the milliwatt range which might have applicability to this function.

7. Manned Spacecraft - NASA's Manned Orbital Research Laboratory and Air Force's Military Orbital Development System are under study. Dependable power in the low kllowatt range is needed for life support systems. 


\section{Radiation Effects}

1. Industrial Processing - The utilization of radiation as a processing tool to create new materials or improve current processes is now becoming a reality. Several industries are now using process radiation or contemplating use within the near future. These applications are too scattered and unrelated to constitute a self-sustained industry but progress is being made toward that goal. The following are specific processes which are at the stage of development where it is possible to make a tentative prediction of future market volume:

a. Medical Supplies - (Sutures, catheter kits, bandages, syringes, surgical tools, etc.)

b. Special Polymeric Materials - (Plastic materials with special properties).

c. Wood Plastic Combinations - (Wood impregnated with plastic monomers, followed by radiation polymerization).

d. Bio-Degradable Detergents - (Alkane sulfonates produced with radiation that are destroyed by the naturally occuring organisms in sewage).

e. Chemical Intermediates - (Compounds. outh las etbyl bromide).

f. Research - (New applications and basic research).

g. Bulk Polymers - (Polyethylene, polypropylene, etc.)

h. Hydrocarbon Fuel From Coal Fractions - (Gasoline or kerosene from coal extracts).

1. Sewage Treatment - (Increase of sedimentation rate via radiation treatment).

2. Radiation Processing of Foods - Commercialization of food irradiation is expected to become a reality within the next few years. This expectancy is based on the Food and Drug Administration's approval of irradiated bacon and wheat and wheat products for public consumption. FDA is currently evaluating potatoes and citrus fruits.

Within the next year, several species of chicken, pork, fish, and fruits are expected to be presented to FDA for approval.

With this additional approval, there will be a justification for private Industry to build irradiation facilities. 
POTENTIAL APPLICATIONS OF AND QUANTITY

REQUIREMENTS FOR FISSION PRODUCT HEAT SOURCES

\section{Military Applications}

1. Navigational A1ds

2. Oceanographic and Weather Monitors East-Coast

West-Coast

Sea-Golng

3. Miscellaneous

Military Programs

4. Military Communications

Satellite (Air Force)

\section{Approximate \\ Generator Power \\ Watts (e) Generator*}

10

$$
\begin{aligned}
& 20-120 \\
& 20-120
\end{aligned}
$$

60

100

30

(Classified)
No. of

Potential

Generator 8

1964-1968

260

$$
\begin{gathered}
40-150 \\
60-130 \\
17
\end{gathered}
$$

$$
\begin{array}{r}
16,800 \\
1,020
\end{array}
$$$$
18,800
$$

(Classified)

(Classified)

(C1assified)

(Classified)

(Classified)

(Classified)
Comments

Decided advantage

High probability

Price dependent

Price dependent

Price dependent

Decided advantage

Decided advantage High probability

Other Government and Civilian Applications

1. Weather StationsInteragency

Price dependent

2. Mavigational Aids

Alaskan \& Aleutian Shore Lights

Buoys - Alaskan Waters

Other Beacons \& Buoys,

U. S. Coast Guard

Gulf of Mexico Oil Well

Buoys, Civillan

10

10

50

50
68

88

27

100
5,000
Price dependent

Price dependent

Price dependent

Price dependent

* At end of mission life 


\section{TABLE I (contd)}

POTEHTIAL APPLICATIONS OF AND QUANTITY REQUIREMENTS FOR PISSION PRODUCT HEAT SOURCES

0 ther Government and Civilian Applications

\begin{tabular}{cr} 
Approxdmate & No. of \\
Generator Power & Petential \\
Gatts(e) Generators \\
Wats & $1964-1968$ \\
\hline
\end{tabular}

Total Requirements

3. Unattended Seismic Stations

Watts (e)

Comments

4. Missile Range Underwater Splash Detectors and Tracking Ship

Position Pixers (STAR)

6. Underwater Cable Repeaters

7. Manned Spacecraft
60

10

20

1

10

(C1assified)
50

30

12

(Classified)
3,000

2,620

600

12
Decided advantage High probability

Price dependent

Price dependent

Price dependent

Not price dependent

Possible Total Requirements During 1964-1968 Period-

(Classified)

If all systems are assumed to operate at an energy conversion efficiency of $5 \%$, their total fuel inventory at the end of the design mission lives is 260 megacuries of Strontium-90 equivalent. (This is not to be construed to mean that each system described would be fueled necessarily with Strontium-90, since other fission products may be more suitable in specific applications).

* At end of mission 11 fe 
POSSIBLE FISSION PRODUCT USAGE FOR INDUSTRIAL IRRADIATION PROCESSING, '1968 티

1. Industrial Radiation Processing

C8-137, Megacuries

Sr-90, Megacuries

Medical Supplies

Special Ploymeric Materials

Wood Plastic Combinations

B10-Degradable Detergents

Chemicals (Intermediates)

Research

Bulk Ploymers

Hydrocarbon Fuels from Coal

Sewage Treatment

2. Food Irradiation

.15 billion pounds of Irradiated food

Total

$$
\begin{array}{r}
5.0 \\
1.0 \\
20.0 \\
50.0 \\
4.0 \\
1.0 \\
10.0 \\
5.0 \\
5.0 \\
\hline 101.0 \\
250.2 / \\
\hline 351.0
\end{array}
$$$$
2.0
$$$$
10.0
$$$$
12.7
$$

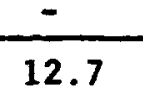

1/ Based on conceptual HIP products prices of $\$ .10$ per curle for Cs-137 and $\$ .13$ per curie of Strontium-90. Only 1968 requirements shown.

2/ This amount could Increase by 500 megacurles per year for annual replacement.

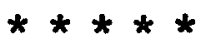

TABLE III

POTENTIAL REQUIREMENTS - SUMMARY (1964-1968)

\begin{tabular}{ccc} 
& \multicolumn{2}{c}{ Megacurie8 } \\
\cline { 2 - 2 } & Sr-90 & C8-137 \\
Heat Source Applications & $260 *$ & - \\
Radiation Applications & $\frac{13}{273}$ & $\frac{351}{351}$ \\
Total
\end{tabular}

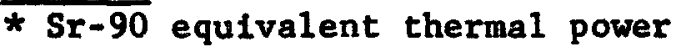


In the tables above, those applications indicated as having a decided advantage are ones with mission of utmost importance to the using agency. These miselons require dependable power and are so located that refueling is almost impossible or extremely expensive. Long lifetime is also usually a requirement.

Price dependent items are those which must compete with conventional methods of power generation on an economic basis. These competing usages would cover battery-operated or petroleum-operated power generators in such applications as buoys, weather stations or cable repeaters. Costs calculations include capital investment, replacement parts, maintenance, etc.

Items not price dependent are those essential to an operation, yet which have a competing source of energy. Price of power is not the first consideration in selecting the fuel. Performance on the job is the important criterion. Examples of such applications are the man-in-8pace program and other space activities which require dependable power generation over a wide range of conditions. Isotopes may have a disadvantage in some of these programs because of radiation safety problems and short supply. However, as competing techniques become outmoded or the isotope supply and safety problems are eased, some change of emphasis in this area is seen.

It is anticipated that as Department of Defense and NASA data gathering programs in remote areas become more sophisticated, the dependence upon isotopic powered generators will become much greater.

Certain of the applications have a very high probability of using isotopic fuel during the next five years. These include those already budgeted and others of such a nature and urgency that only isotopic power can meet the need requirements. 
ECONOMIC COMPARISON

OP

THE USE OF FISSION PRODUCTS

AND

OTHER ENERGY SOURCES IN POWER APPLICATIONS

Division of Isotopes Development

U. S. Atomic Energy Commission

Washington, D. C. 20545

February 1964 
Page

A. Introduction 3

B. Coast Guard Navigational Buoys Lights and Beacons

1. Light Buoys 5

2. Fixed Shore Lights 9

C. Other Buoy Applications 11

D. Undersea Acoustic Systems 12

1. Range Instrumentation 12

2. ASW Applications 13

3. Undersea Electronics 14

E. Weather Stations 16

F. Summary of Results-Economic Study 19

Fuel Cost Chart $\quad 20$ 


\section{ECONOMIC COMPARISON \\ OF \\ THE USE OF FISSION PRODUCTS \\ AND \\ OTHER ENERGY SOURCES IN POWER APPLICATIONS}

This study evaluates several major applications of heat producing isotopes, a portion of which, if utilized as Radioactive Power Generators, would require fission product isotope production equivalent to that of a HIP facility. It was felt that it was not necessary to make an economic comparison of all potential usages if sufficient fustification was established from those studied to Indicate a potential requirement equivalent to the programmed HIP output. The different power applications considered were: (1) Coast Guard Navigational Buoys, Lights, and Beacons, (2) Undersea Electrontc Systems, and (3) Weather Stations.

Comparative costs were determined for existing methods and other proposed conventional methods of power generation and compared to radiolsotope power generation. These costs include capital investment, amortized cost and maintenance for the power units.

\section{A. Introduction}

Several applications of direct conversion power supplies employing radioisotope heat sources are examined from the logistic/economic point of view, to demonstrate the validity of employing these novel sources of energy rather than the more conventional power supplies already available or under development. Certain premises and assumptions must be made in each case, since insuffictent numbers of radioisotope power systems have been completed and put into operational use to collect meaningful cost information. Furthermore, the cost of providing, maintaining, and replacing conventional power supplies in remote areas is also in the realm of nebulous information, since the using agencies have, in most cases, 
justified expenses on the basis of operational necessity rather than on purely economic factors.

B. Coast Guard Navigational Buoys, Lights, and Beacons

Information from the USCG ${ }^{1}$ reveals that this agency operates the following aids to navigation which do not rely upon commercial electrical power, local motor generator sets requiring direct maintenance, or manned vehicles such as lightships:

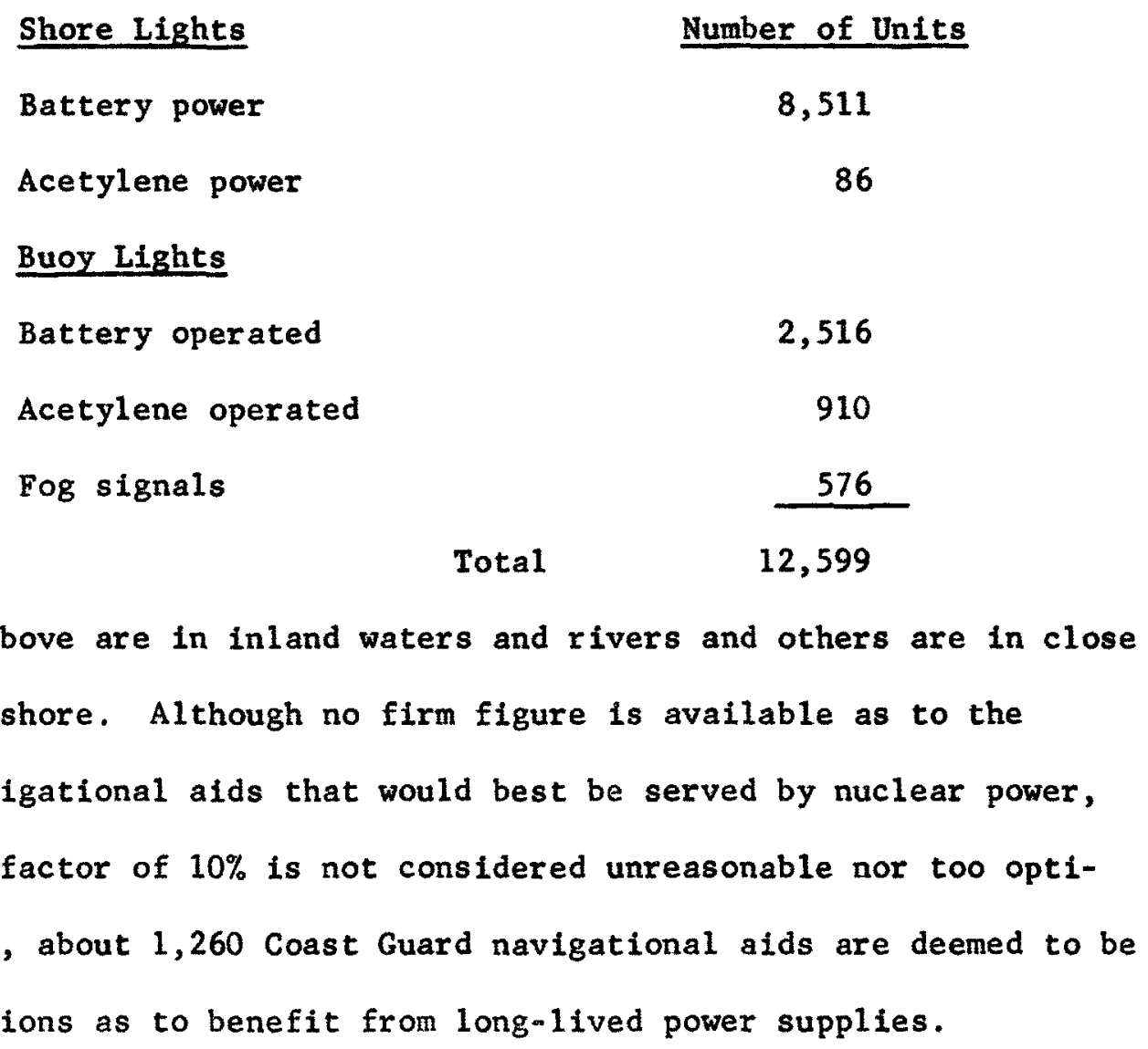

Ref. 1 Personal Communication with LCdr. C. F. Piestrup, USCG, July 13, 1962.

Isotopic Generator Business Analysis, September 1962, Martin Co. (proprietary document) 
In the SNAP White Paper evaluation of isotopic power systems, a potential requirement of 160 generators in the 1963-1967 time period is visualized ${ }^{2}$ for use in Coast Guard navigational aids, the power requirements being in the range of 5-100 watts(e) per unit. It, therefore, appears reasonable to expect that the more immediate potential requirement (1963-1967) comprises perhaps $13 \%$ of the total Coast Guard requirement. Requirements of between 5 and 50 10-watt $(e)$ generators (or equivalent number-power combinations) per year are anticipated for this purpose in the 1968-1975 time period, or between 30 and 300 units. Once again, the numbers are within the same order of magnitude.

1. Light Buoys - It is possible to compare conventional and nuclear power costs for light buoys in the Alaskan waters. Three types of batteries are considered:

a. Lead acid - These barteries are in common use and cost data are accurate and readily available. They have a six-year life and must be recharged at least once each year. Because of deterioration, damage on handling, etc., the 17 th CG District maintains a spares inventory of $50 \%$ of the number of batteries in active use.

b. Air-depolarized - This is a new type of battery now under development by the Coast Guard, characterized by its relatively long Ii:e without meintenance, of about two years. Accurate cost data nre not availabie, but a cost of 1.5 times that of a lead acid battery of the same capacity is assumed. The battery is employed for one cycle only and is then discarded.

Ref. 2 Table 2 Proposed AEC Staff Paper - SNAP Program 
c. Strontium-90 Fueled Thermoelectric Generator - A design improvement beyond present day hardware is anticipated which will provide a generator with a useful life of 15 years and a thermal-to-electrical conversion efficiency of at least $6 \%$. The cost of such a 10-watt generator is arbitrarily set at $\$ 12,000$. A smal1 nickel-cadmium battery is employed in conjunction with the generator to store electrical energy, and this battery must be changed at periods probably dictated by other maintenance required on the buoys, such as changing light bulbs, or overhauling the buoy proper.

of the several hundred buoys and lights operated by the $17^{\text {th }}$ CG District, only the so-called $8 \times 26$ buoys are analyzed here. They are serviced by $180^{\circ}$ buoy-tenders, and the operating costs of these ships are the greatest cost factor in the over-all cost picture. A summary of relative costs for the three types of batteries is given below; for simplicity, all cost factors which are equal in the three cases are not shown; i.e., maintenance and replacement of electrical equipment, cost of buoy, maintenance of buoy, capital cost of buoy tender. 


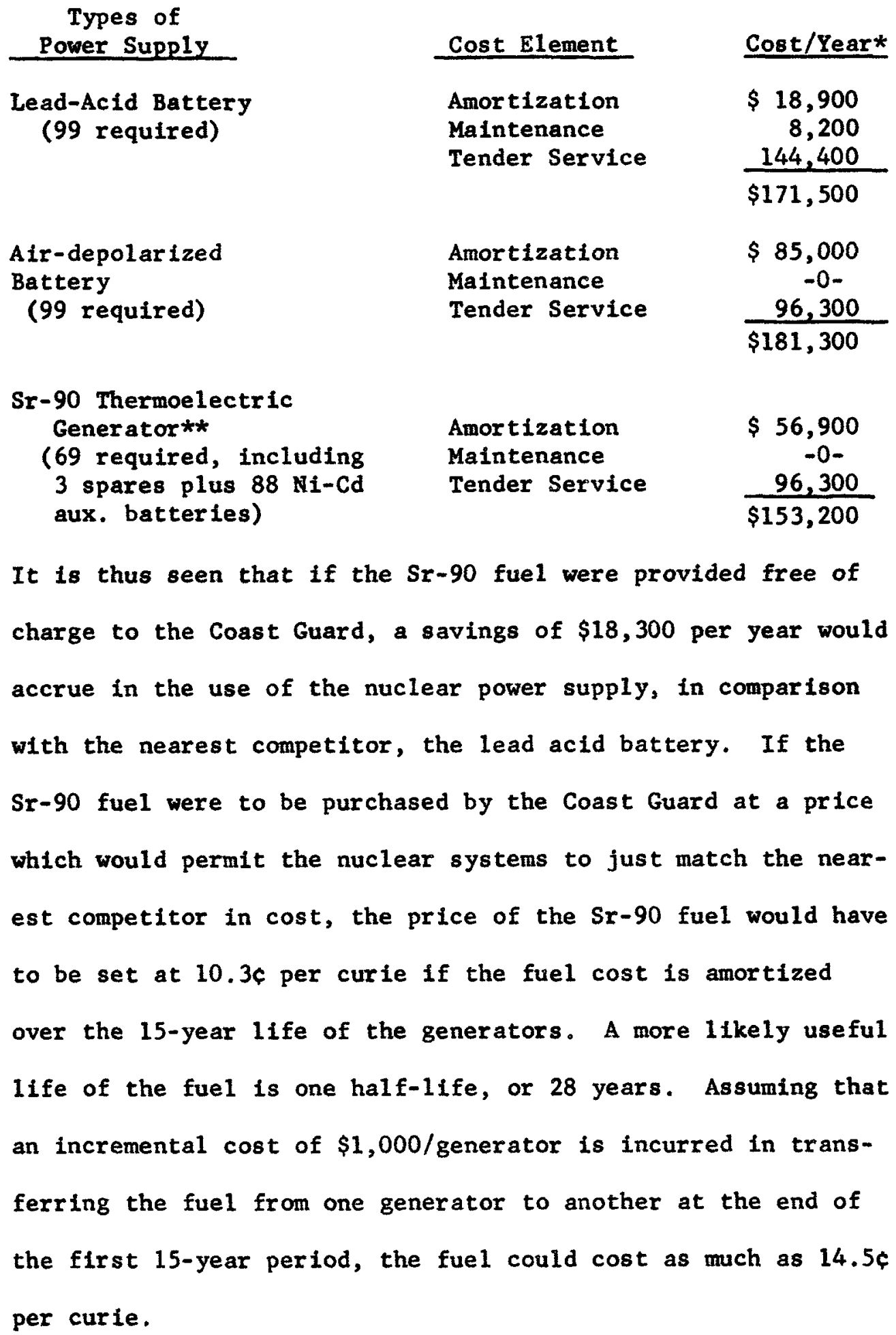

* For 66 buoys maintained in the field out of a total of 88 buoys avallable.

** Without fuel costs included. 
In the above analysis, 2.65 megacuries of $\mathrm{Sr}-90$ are required to fuel the 69 generators initially, based on a thermoelectric conversion efficiency of $6 \%$ and a decay period of 15 years. Some inaccuracy is introduced by the assumption that the 15-year old fuel can be transferred to another generator with the same conversion efficiency, but this effect should be negligible for the purposes of this study, particularly if we assume an $8-1 / 2 \%$ efficient direct conversion system will be available in 1980, the end of the first 15-year period.

In light of the above analysis, it is necessary to point out that the air-depolarized battery was accepted for operational use in July 1963, and that costs for this type of system are expected to drop considerably. Also, other sources of energy are under development by the Coast Guard, e.g., propane-fired thermoelectric generators, which also show promise. In other words, competitive non-nuclear systems are under active consideration and the cost comparison will change almost continuously with time. If the capital cost of the air-depolerized battery becomes equal to the lead acid battery, for example, and has twice the storage capacity (as stipulated earlier), then it becomes almost exactly competitive with a $\$ 12,000$ nuclear generator with free $\mathrm{Sr}-90$ fuel.

The propane-fired thermoelectric generator is not yet qualified for actual buoy service in Coast Guard operations. 
2. Fixed Shore Lights - Since shore lights are less susceptible to attack by the environment than are light buoys, the possibility of extending the service cycle of shore lights is greater. Those lights which require self-powering are usually in remote and rugged areas and must be serviced by ships or by overland parties. There are several areas along the coast of the continental United States and other U. S. territories, which are routinely malntained by the Coast Guard and by private groups through what is considered hazardous duty because of the inaccessibility of the lights. The light-tending ship in Alaskan waters must travel 1,900 miles to service 35 shore lights in one case, and 4,400 miles for 33 lights in the second case. It is proposed that these lights be serviced from the tender by means of a large H04S helicopter, capable of carrying batteries or a nuclear generator. In a most conservative manner, each light is assumed to be charged only one day of tender service and one day of helicopter service for each maintenance visit. The standard Coast Guard charge for the tender is $\$ 100$ per hour, according to the Coast Guard Aids to Navigation Manual. The cost of the helicopter is $\$ 250$ per day, including amortization of two aircraft over a six-year life and full operating costs.

Discussions with Coast Guard personnel indicate that there are real prospects that the life of the electrical apparatus in fixed lights can be increased to five years. The frequency at which the batteries must be changed, if less than five years, then becomes the critical costdetermining factor. In a light requiring the equivalent of 5 wats of continuous electrical power, $43.8 \mathrm{kwh}$ of energy are consumed per year. The latest information available on air-depolarized batteries ${ }^{3}$ indicates

Ref. 3 Personal communcation with LCdr. C. F. Peistrup, USCG, Aug. 14, 1963. 
that a 4,000 ampere-hour battery is now available for a cost of \$515. The voltage regulation of this type of battery is very poor, so it is necessary to utilize a battery that is oversized with respect to the desired load voltage, i.e., a 16-volt battery is used in conjunction with an external voltage regulator to provide 12 volts to the load. For the purposes of this study it is optimistically assumed that the full 4,000 ampere-hours capacity is available to the load at 12 volts, and thus the battery delivers 48 kwh of energy.

In other words, no allowance is made for regulation or aging losses. Since the frequency of battery changing cannot be adjusted to coincide exactly with the expiration of the battery, it is assumed for the purposes of this study that two such batteries will power a shore light requiring $44 \mathrm{kwh} /$ year for a period of two years - a period within the shelf life of the batteries.

The two-year cost of servicing battery-powered shore lights in a remote region then is:

\begin{tabular}{lrr} 
Tender charge, $\$ 100 / \mathrm{hr} \times 24$ hro. & $\$ 2,400$ \\
Helicopter charge, $\$ 250 /$ day & 250 \\
Battery, $2 \times \$ 515$ & Total & 1,030 \\
\hline & & $\$ 3,680$
\end{tabular}

The annual cost is therefore ascribed to be $\$ 1,840$. In comparison, a 10-watt nuclear generator, a $\mathrm{DC}-\mathrm{DC}$ converter and a nickel-cadmium storage battery are required to deliver 5 watts of equivalent useful power to a shore light. Such a system would require maintenance only at the five-year interval dictated by the electrical apparatus comprising the light itself. Employing generator cost data used earlier, the five-year service cost of the 
nuclear-powered shore light is:

$$
\begin{aligned}
& \text { Tender charge, } \$ 100 / \mathrm{hr} \times 24 \mathrm{hrs} . \quad \$ 2,400 \\
& \text { Helicopter charge, } \$ 250 / \text { day } 250 \\
& \text { Generator, } \frac{\$ 12,000}{15} \times 5 \quad 4,000 \\
& \text { Sealed cell Ni-Cd battery \& converter } \quad 500 \\
& \text { Total } \$ 7,150
\end{aligned}
$$

The annual cost is, therefore, computed to be $\$ 1,430$. An annual saving of $\$ 410$ per light might therefore be anticipated on an extremely conservative basis, provided that no assessment is made for the Sr-90 fuel in the generator. Such a generator would contain 38.4 kilocuries of Sr-90 at the beginning of its life, based on $6 \%$ conversion efficiency and a syetem ilfe of 15 years. The so-called "break-even cost" of the Sr-90 is therefore $16.0 \mathrm{c}$ per curle if the acquisition cost of the fuel is amortized over 15 years. Employing a 28-year useful fuel $\mathcal{L}$ fe and a fuel transfer cost of $\$ 1,000$, as in the previous portion of this study, leads to a breakeven fuel cost of 25.0 c per curle.

C. Other Buoy Applications - The foregoing analysis shows that in two speciallzed cases, power supplies for Coast Cuard use become economically competitive with Strontium-90 fuel cos of $15 \%$ to $25 \%$ per curie. The Coast Guard has indicated that a much larger market can be Jeveloped if a radioisotope power supply can be developed to deliver power at $\$ 10$ per kilowatt hour. This cost can be achleved with $5 x-90$ fuel costs on the order of 10द per curie, and would apen up a market potential of 75 megacuries. *

Twenty-five thousand electrical watts Installed capac1ty. 


\section{Undersea Acoustic Systems}

1. Range Instrumentation - The use of radioisotope power supplies to power deep-ocean acoustic devices as alds to submarine navigation and to provide range instrumentation has been under active consideration by the AEC and the U. S. Navy. The systems studied included:

a. Central power system with cable network

(1) Fossil-fuel thermoelectric generator

(2) Solar cell power supply

(3) Diesel generator

b. Individual beacon power supplies

(1) Radioisotope thermoelectric generator

(2) Storage battery

The comparative acquisition costs of the various power supplies are as follows:

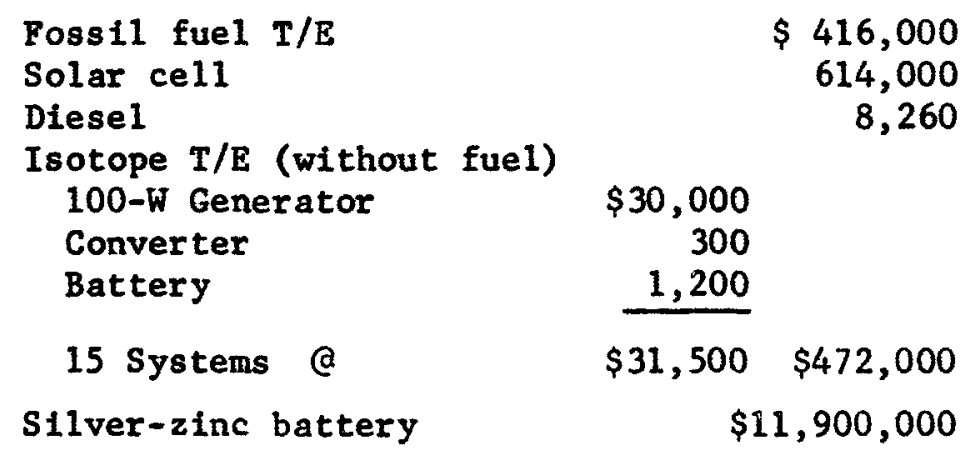

In addition, the central power stations require the use of cable to reach the 15 sonar stations assumed in the systems. The cost of the cables, not including Installation costs, is a minimum of $\$ 698,000$. (The minimum cable cost does not give the most reliable system, however). Thus, the most economical central station system costs about $\$ 706,000$. Quite obviously, no consideration need be given to the silver-zinc primary batteries, which are sized to last only two years and which are prohibitively expensive. It is estimated that the cost 
of emplantment only of the 379 miles of cable would be $\$ 200,000$, not including cable cost. If 15 self-contained systems with radioisotope power supplies were used, it is estimated that the cost of emplantment of the 15 systems would be $\$ 90,000$. For the purposes of this study, 1t will be assumed that the diesel maintenance and fuel costs are equaled by extraneous expenses associated with the nuclear power sources, and that each system has a 10-year 1 ife. These assumptions are conservative with respect to the nuclear system. Each isotopic generator would contain 338 kilocuries, based on $5 \%$ efficiency and 10-year 1ife. The break-even cost of the Sr-90 fuel is, therefore, $6.8 \mathrm{c}$ per curie. The total fuel requirement is about 5 megacuries. It is important to note that in the above example, only 379 miles of cable would have been laid to connect the 15 beacons with the shore power stations.

2. ASW Applications - In ASW applications under active consideration, such as East Coast and West Coast submarine surveillance networks, the positioning of active or passive sonar detectors would be of such nature as to make the use of underwater cables and shore power stations prohibitively expensive. Let us assume a 2,000-mile-1ong passive/active submarine barrier survelilance system stretching from Newfoundland to the Island of Barbados. All figures represent millions of dollars:

\section{CABLE POWERED}

Acoustic Coder Power and

Profectors Cable Batteries Decoder Comm.Backup Total
19.7
85.1
1.4
15.9
3.4
125.5 


\section{RADTOISOTOPE POWERED}

Acoustic

Coder

Projectors Cable Power Fuel Decoder Comn. Backup Total

19.7

$34.7 \quad 20.4 \quad 31.1$

15.9

.97

122.7

The costs estimated in the study included 146 120-watt radioisotope generators at $\$ 140,000$ each. Current estimates of that quantity of 120-watt generators would be $\$ 50,000$ each. The fuel costs used were estimated on the basis of 10 -year ilfe, $6 \%$ generator efficiency, and $50 c$ per curie. Using up-to-date generator costs $\$ \$ 50,000$ in 1 ieu of $\$ 140,000$ per generator), the break-even fuel cost would be 71 c per curie. Or, given fuel at 20 per curle, the nuclear-powered system total costs would be $\$ 94$ million compared to the $\$ 125$ million cablepowered system.

The fuel required for the system studied is 62 megacuries of Sr-90. Other intangible benefits which accrue to radioisotope power supply include the following:

a. Conventional cables are often cut by accident, and they are susceptible to covert sabotage.

b. The underwater power supplies operate in a stable environment and are not subject to typical fluctuation in surface weather conditions.

c. The repetitive hazards involved in servicing power supplies at frequent intervals in remote locations are not experienced.

3. Undersea Electronics - Early in 1964, contracts were let to Martin Company and Minnesota Mining \& Manufactwring Company to build 10watt radfoisotope generators for undersea use. For the intended mission, weight and volume are critical. The use of radioisotope power provides a system well within the volume and weight limits. 
For comparison purposes a battery power supply to meet the same requirements has been calculated. A silver-zinc battery was selected because it has the highest energy-to-volume and energy-to-weight ratio and lowest self-discharge rate of the commercially available batterles. By replacing the radioisotope generator and associated converter, battery and pressure vessel, and filling the unused allowable length with silver-zinc cells, a 1200 ampere-hour 24-volt battery results. A comparison of the radioisotope power supply and battery is as follows:

\begin{tabular}{lcrr} 
& RTG & Battery \\
\cline { 2 - 2 } Cost, Dollars & $19,000 *$ & 23,000 \\
Life, months & 36 & 9
\end{tabular}

* Not including fuel

Thus, strictly on a capital cost basis, the break-even cost of the Strontium-90 fuel is $16 \%$ per curie.

If the costs of three additional replacement systems to cover the three-year period and the cost of emplantment are Included as shown below, the break-even cost of the fuel becomes $\$ 16.10$ per curie.

SYSTEM WITH RTG - 36 MONTHS

$\begin{array}{lr}\text { Generator Cost } & \$ 19,000 \\ \text { Electronics System } & 50,000 \\ \text { Emplantment } & 60,000 \\ \text { Total Cost } & \$ 129,000\end{array}$

SYSTEMS WITH BATTERY - 36 MONTHS

Battery Cost, 4 a $\$ 23,000$

Electronics, 4 @ $\$ 50,000$

$\$ 92,000$

Emplantment, 4 a $\$ 60,000$

200,000

Total Cost

$\frac{240,000}{\$ 532,000}$ 
If the limitation on volume and weight is ignored, the silver-zinc battery required to provide power to the system for the three-year period is as shown below:

\begin{tabular}{llr} 
& RTG & Battery \\
\cline { 2 - 3 } & & \\
Volume, cu. ft. & Less than 5 & 40.5 \\
Weight, 1bs. & Less than 1000 & 5,600 \\
Cost, dollars & $19,000 *$ & 112,000
\end{tabular}

* Not including fuel

In this case, the break-even price for the 25,000 curie fuel source for the generator is $\$ 3.72$ per curie. It is estimated that as many as 100 power sources will be required, representing 2.5 megacuries of fuel.

E. Weather Stations - Unmanned automatic weather buoys have been used for several years to provide hurricane storm intensity data hampered by shortlife power supplies. The use of weather buoys will increase in the near future; both the Weather Bureau and Navy Bureau of Weapons are currently buying additional weather buoys. The SNAP 7D 60-watt thermoelectric generator is designed to provide power to satisfy the requirements of one Navy weather buoy. The economics of the use of nuclear power supplies on these buoys near the $U$. S. coast line is comparable to the economics of power supplies for Coast Guard buoys, i.e., radiolsotope power supplies become feasible with fuel costs of 14.56 per curle if amortized over a 28-year period. As the distance from the $\mathbb{U}$. So coast increases, the economic balance becomes more and more favorable for nuclear systems because of increased resupply costs for short-term (battery) power supplies. For example, for weather buoys 500 miles fron shore requiring yearly visits for battery recharging versus biyearly visits for electronic maintenance for nuclear powered systems, the fuel break-even costs skyrocket to $\$ 1.20$ 
per curle on the same basis. Weather buoy generator requirements are expected to exceed 100, equivalent to 7.7 megacuries of $\mathrm{Sr}-90$ fuel.

1. Cost comparisons for nuclear powered automatic weather stations versus manned stations in remote areas are difficult to make for two reasons :

a. Lack of cost data.

b. Automatic stations do not provide the same data as manned stations.

Five manned weather stations in the Arctic area are operated jointly by the U. S. and Canadian Weather Bureavs at Alert, Eureka, Isachsen, Mould Bay and Resolute. The $U_{\text {. }} \mathrm{S}$. Weather Bureau share of the operating costs for last year was $\$ 600,000 .^{*}$ This includes some expenditures for capital equipment, runway maintenance, communications costs, and logistic support. In addition to the temperature, barometric pressure and wind data provided on a 3-hourly schedule by the Axel Heiberg Weather Station, the manned stations provide the following measurements:
a. Upper air data.
b. Ozone.
c. Solar radiation.
d. Humidity.
e. So11 temperature.
f. Visibility and cloud cover.
g. Ice thickness and formation.

Discussion with Graham Bowle, Budget and Management, U. S. Weather Bureau, Washington, D. C. 
h. Special micrometeorological data.

i. Hour1y observations.

The Danish Government states that the operating costs for manned weather stations on Greenland is $\$ 100,000$ per year. Additional stations in the Arctic area are desirable; however, the cost of supplying manned stations and the difficulty of recruiting personnel has hampered expansion. Weather stations spaced on 150-mile centers are desirable to obtain thorough synoptic mapping inputs. This would require 60 stations in the Canadian Northwest Territory and Greenland, between the 70 th and 80 th parallel where now only 15 are operated.

The WMO is programming $\$ 165,000$ per year per station for operation of its planned 100-station world-wide network. Most of these stations will be located in the tropics.

It is estimated that radioisotope fueled weather stations, similar to the Axel Heiberg station, can be built for $\$ 100,000$ each, not including fuel. The station can be readily modified to accept as many as 12 additional channels of data and to provide hourly transmissions. Considerable development work is required to provide automatic sensors for some of the additional desirable parameters.

An unattended automatic weather station designed to provide all the data 1 isted above except upper alr data would cost approximately $\$ 200,000$, including a 10-watt radioisotope generator, but excluding fuel. The station could be amortized over a 3-year period at $\$ 70,000$ per year if fueled at $20 \mathrm{f}$ per curle. 
F. Summary of Results-Economic Study - Tabulated below are the fuel requirements and break-even fuel costs for the isotopic power applications studied in preparing this report. It must be emphasized that the applications studied represent only a portion of the total anticipated radiolsotope fuel requirement in the 1964-1968 time period, which, in turn, are but a fraction of the total requirement for remote auxiliary power supplies.

\section{Applications Studied}

CG Alaskan Light Buoys (66 of 12,600 1ights)

CG Alaskan Fixed Lights

Other Buoy Applications

Undersea Range

ASW

Undersea Electronics

Weather Buoys

Weather Stations
Fuel Requirement

Megacuries
Break-Even Cost

Cents per Curle
2.6
14.5
2.7
75.0
5.0
25.0
10.0
.6 .8
62.0
2.5
7.7
71.0
6.0
1610.0
14.5
20.0 


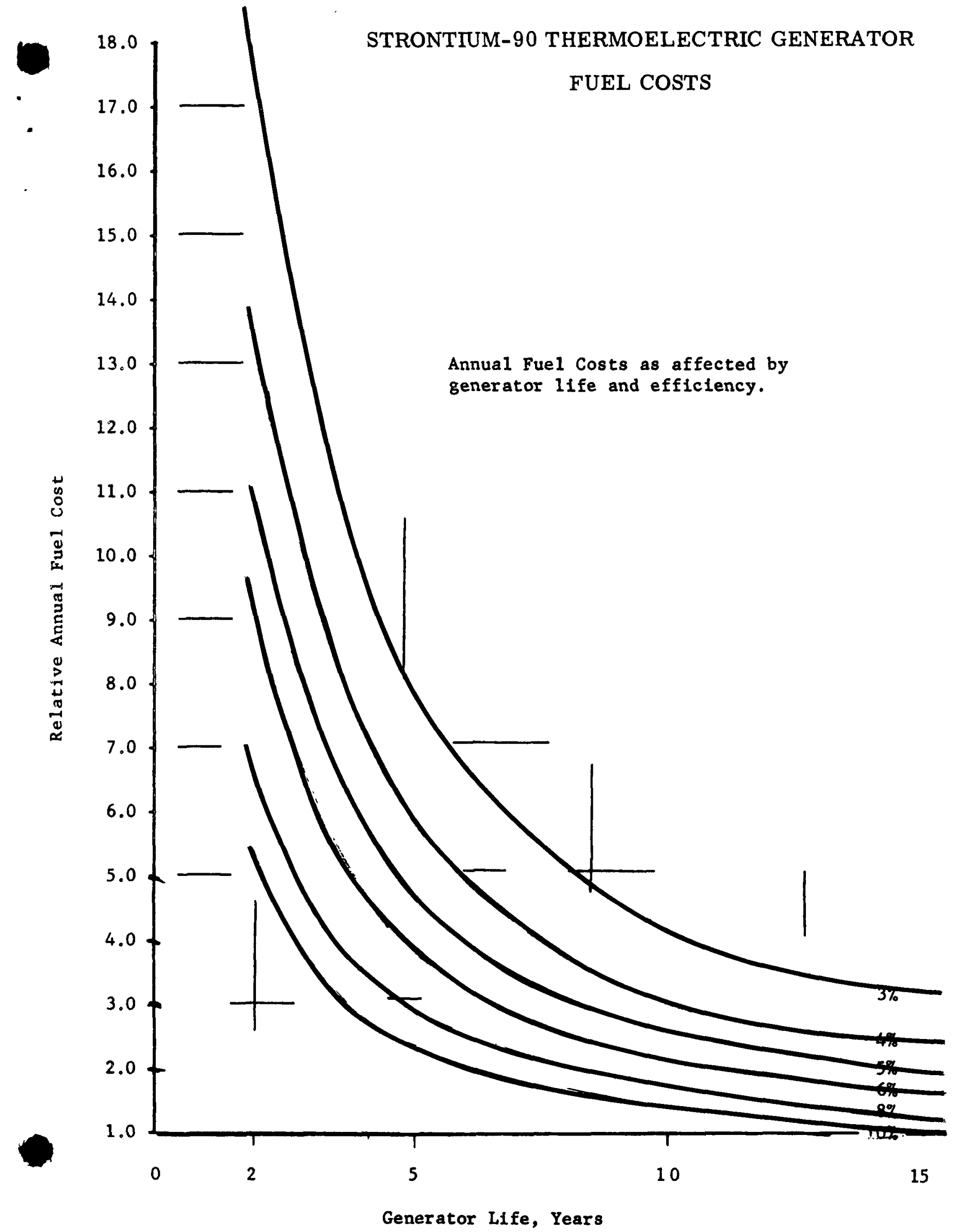




\begin{tabular}{|c|c|c|}
\hline 15-Year Generator Life & Sr-90 Cost/Curie & Fue 1 Cost 3 \\
\hline $\begin{array}{l}\frac{10 \text { watt electrical }}{17} 166.6 w(t) \\
\frac{17}{2} / 24,990 \text { curles } \\
\underline{3} / \quad 38,360 \text { curies }\end{array}$ & $\begin{array}{r}\$ .05 \\
.10 \\
.15 \\
.20 \\
.25\end{array}$ & $\begin{array}{r}1,918.00 \\
3,836.00 \\
5,754.00 \\
7,672.00 \\
9,590.00\end{array}$ \\
\hline $\begin{array}{l}\text { 25-watt electrical } \\
\frac{1}{2} / 16.5 \text { w(t) } \\
\frac{2}{3} / 62,475 \text { curies } \\
\text { / } 95,900 \text { curies }\end{array}$ & $\begin{array}{r}\$ .05 \\
.10 \\
.15 \\
.20 \\
.25\end{array}$ & $\begin{array}{r}\$ 4,795.00 \\
9,590.00 \\
14,385.00 \\
19,180.00 \\
23,975.00\end{array}$ \\
\hline $\begin{array}{l}\frac{50 \text { watt electrical }}{1 / 233.0 \text { w(t) }} \\
\frac{1}{2} / \frac{124,950 \text { curies }}{3 /} 191,800 \text { curies }\end{array}$ & $\begin{array}{r}\$ .05 \\
.10 \\
.15 \\
.20 \\
.25\end{array}$ & $\begin{array}{r}\$ 9,590.00 \\
19,180.00 \\
28,770.00 \\
38,360.00 \\
47,950.00\end{array}$ \\
\hline
\end{tabular}

I/ Calculated at $6 \%$ conversion efficiency

2/ Required fuel loading at end of 15 years

3/ Initial loading for 15-year use

150 cur les/watt(t) 